\title{
COMMISSION 41: HISTORY OF ASTRONOMY (HISTOIRE DE L'ASTRONOMIE) (a joint IAU-IUHPS Commission)
}

\author{
J. D. NORTH \\ Filosofisch Instituut \\ Rijksuniversiteit Groningen \\ A-weg 30, $9718 \mathrm{CW}$ Groningen \\ The Netherlands
}

The scientific programme at the 21st General Assembly of the I. A. U., held at Buenos Aires, Argentina, between 23 July and 3 August 1991, occupied four sessions. The general theme of the historical meetings was 'The Preservation and Conservation of Astronomical Archives and Instruments', and thirteen papers were presented by members, or on their behalf. These were: The demise of the Bush Barrow lozenge (J. D. North, Presidential Address); La sauvegarde du patrimoine . source de documentation historique (S. Debarbat, President Elect); Masonry instruments at Delhi Jantar Mantar and the programme for their restoration (G. S. D. Babu); Initiatives taken by the Italian Astronomical Socicty for the cataloguing and preservation of archives and instruments of historical interest (E. Proverbio); Safeguarding the history of a national observatory: the U. S. National Observatory (S. J. Dick); The preservation of Penuvian archaeoastronomical sites (M. L. Aguilar); On the conservation of the astronomical instruments in Romania (E. Botez and T. Oproiu); The archives of a French astronomer: Henri Chrétien (F. Le Guet Tully and others); The probable ancient determination of the planetary periodic time of reference (Y. Maeyama); An overview of extant astronomical records from the pre-telescopic period (K. Yau); Three centuries of astronomy in Marseilles (R. Augarde, Y. P. Georgelin, M.-J. Meynent, M.-L. Prevot); Joannes Exarch and the distribution of ancient Greek astronomy among Slav peoples (N. S. Nikolov).

A video film prepared by Peter Parodi and Horacio Tignanelli, both of Argentina, 'Recent research into the astronomy of Tiwanacu', was shown during one session.

Officers for the session 1988-1991 were as follows: J. North, President; S. Debarbat, Vice-President; J. Eddy (former President), A. A. Gorstein, D. DeVorkin, Xi Ze-Zong. At the business meeting of the Commission held on 26 July, the following officers were duly elected, taking into account the earlier postal ballot among members:

President:

Vice-President:

Organising Commission:
S. Débarbat

S. M. R. Ansari

S. J. Dick

M. G. Firneis

K. P. Moesgaard

J. D. North

At the business meeting a review was made of various assemblies held in the period 1988-1991, at which the Commission has participated, notably the 18th General Assembly of the 1.U.H.P.S. at Hamburg and Munich (August 1989) and the conference held in Vienna on the theme 'The Interaction of European and Asian Astronomy' in September 1990. This last was organised locally by 
M. G. Firneis and her colleagues at the Astronomical Institute and the Austrian Academy of Sciences. It had been hoped to follow the Buenos Aires meetings with an archaeoastronomy meeting in Peru, that is, in August 1991, but troubles that hit that country unexpectedly have meant that it will be held instead in 1992. The organiser will be M. L. Aguilar, U. S. M., San Marcos University, Ap. postal no. 11, 0481 Lima.) Various other meetings are under consideration by the Commission, among them one planned for 1993 relating to the Struve family (organiser H. Eelsalu, Tartu Astrophysical Observatory, Estonia), and another to commemorate the bicentenary of the birth of John Herschel (organiser B. Warner \& others, Royal Society of South Africa, for 1992). A meeting in which the Commission will participate is due to take place at the B. M. Birla Science Centre in Hyderabad and at Jaipur between 12 and 16 December 1991 ('Indian and other Asiatic Astronomies', B. G. Sidharth or S. M. R. Ansari).

Further discussion took place around the state of the General History of Astronomy, supported by the Commission since its inception (see below). In view of the main theme of the Commission's meetings, it was decided on a unanimous vote of those members present to make a formal resolution to be presented to the General Assembly in its closing session. This was done jointly by Commission 41 and Commission 5, and was

that the Union supports an initiative taken by Commissions 41 and 5 (1) to establish a register of the whereabouts of all extant astronomical archives of historical interest; (2) to impress on observatories and other institutions their responsibility for the preservation, conservation, and where possible cataloguing of such archives; (3) to search for an institution that will allocate space and funds for maintaining such a register and publishing it.

It was not felt that the proposal should take instruments into account at this stage, since the problems presented there are of a very different character; but if the one project makes progress, the other should certainly follow in its train. The first objective is to stop the wholesale destruction of materials of historical value; the second is to make the whereabouts of material better known to scholars. Many instances were reported at this meeting of situations where a series of directors of institutes, librarians, and others invested great care in the preservation of materials over a long period, only to be followed by others entirely without a feeling for the past, prepared to sell or destroy their inheritance. The General Assembly endorsed the resolution. The following Working Group was established to look into the possibilities mentioned in the resolution: S. Débarbat (ex officio, President), S. J. Dick, E. Proverbio, B. Hauck (comm. 5), D. Dewhirst (comm. 5).

During the Commission meetings, three members who had died since the last General Assembly were remembered: K. A. F. Fischer, H. C. Freiesleben, and V. Thoren. Victor Thoren was a former colleague of Frank K. Edmondson at Indiana University, who, having the right to propose a name for minor planet $(3717)=1964 \mathrm{CG}$, discovered during the minor planet program on 15 February 1964, wishes to call it (3717) THOREN. The Commission heartily endorsed this idea. Thoren's book on Tycho Brahe had been presented to him only a few days before his untimely and unexpected death, serving perhaps as a reminder of an earlier astronomer than Tycho.

\section{Publications}

The General History of Astronomy was a project that originated within the Commission. Of its four volumes in seven parts, two had appeared at the time of the meeting: vol. ii, Planetary Astronomy from the Renaissance to the Rise of Astrophysics, Part A; and vol. iv, Astrophysics and Twentieth-Century Astronomy to 1950, part A. Of the remaining five parts, four were well advanced in preparation. 